\title{
Facilitating Expansion of African International Trade through Information and Communication Technologies
}

\author{
Emmanuel T. Laryea* \\ Faculty of Law, Monash University, Wellington Road, Clayton, VIC, Australia
}

\begin{abstract}
This article observes that expansion of international trade, particularly exports of appropriate goods, by African economies is important to their growth and development. Unfortunately, Africass share of world trade has been decreasing rather than increase. The continent is behind other continents in developmental terms, despite its many resource endowments. Governance deficiencies (broadly defined) are a major cause of the inability of African economies to manage their resources for sustained growth and development. The article looks at the particular consequences of governance deficiencies on trade expansion and goes on to suggest that the deployment of ICT can ameliorate those deficiencies. It focuses on the potential positive impact of e-governance in general, and e-customs in particular, on trade expansion. It argues that e-governance, including e-customs, has the potential to enhance the international competitiveness of African economies, increase revenues for government, and increase FDI inflows for production and exportation. It concludes that while e-customs is not a panacea for Africa's international trade underperformance, it is an important piece of infrastructure that is relatively easier and cheaper to build, but which has a high beneficial impact on trade expansion. It therefore recommends the implementation of efficient e-customs in African economies that do not yet have such systems.
\end{abstract}

\section{Keywords}

African trade expansion; international trade; trade and African development; good governance; e-governance; e-customs; ICT for development

\section{Introduction}

Many argue that African economies should trade out of poverty into development (i.e., 'trade to develop'). ${ }^{1}$ This is because international trade has the potential to promote their economic growth and development. ${ }^{2}$ There seems to be good evidence that expansion of trade, particularly appropriate exports, is important to

*) LLB (Hons) (Ghana), LLM (Glasgow), PhD (Bond). Senior Lecturer, Monash University, Australia; and Fellow, Tim Fischer Centre for Global Trade and Finance, Bond University, Australia. Email: Emmanuel.Laryea@monash.edu.

1) See, e.g., P. Lilley, C. Short, Sir M. Campbell and M. Hastings, 'Trade Out of Poverty' (2011) 12(12) World Economics 25-32.

2) See, e.g., UN General Assembly Resolution 1707 (XVI), 19 December 1961; G. Bamudo, 'Transnational Law, Unification and Harmonisation of International Commercial Law in Africa' (1994) 38(2) Journal of African Law 125-143, at 128; J. Stiglitz and A. Carlton, Fair Trade for All (Oxford University Press, Oxford, 2005) 11. 
the growth and development of economies. ${ }^{3}$ Most of the Asian economies that have, on the average, outgrown the economies of other regions (developed and developing) in the last two decades have been mainly export-led. ${ }^{4}$ And Africans may be well aware of the benefits of profitable trade; every capital city on the continent throngs with traders. Of course the 'trade to develop' mentioned in this article mainly refers to export trade. That requires African economies to expand their exports by value and volume, and of the appropriate products; not just the raw materials as has mostly been the case. ${ }^{5}$

Unfortunately, Africa's share of international trade has, rather, been declining over the decades, despite the continent's abundant resources and production potential. Portugal-Perez and Wilson compute that Africa's share of world exports "dropped by nearly two thirds in three decades: from $2.9 \%$ in 1976 to $0.9 \%$ in 2006." "United Nations (UN) data, on the other hand, suggests that Africa's share of exports dropped from $5.989 \%$ in 1980 to $3.250 \%$ in $2010 .^{7}$ The figures vary markedly, but they both point to one thing: Africa's share of trade has declined significantly in the last three decades. In effect, the continent's share is far below its potential and what is required for effective economic growth and development. It has become increasingly marginalized in world trade. ${ }^{8}$

The factors for the continent's sub-optimal international trade, and indeed general economic performance, are numerous. They range from low levels of production and productivity in both agricultural and manufactured products, ${ }^{9}$ lack

3) I.F. Razafimahefa and S. Hamori, International Competitiveness in Africa (Springer, Berlin, 2007) 1.

4) Of course there are limitations on the export-led development model itself, but these are not examined in this article. This article proceeds on the assumption that economies reap growth and developmental benefits from trade expansion. For discussions on the limitations on the export-led development model, see, e.g., T.I. Palley, 'Export-Led Growth: Evidence of Developing Country Crowding-out' in P. Arestis, J.S.L. McCombie and M. Baddeley (Eds), Economic Integration, Regionalism, and Globalization (Edward Elgar, Cheltenham, 2003).

5) Africa is no doubt a huge continent, and there are differences in their levels of resource endowments; there are different regions; and differences in the current state and levels of economic development. This article will not look at the specificities of each country or region. In this article, "Africa" is used generally for countries lying mainly south of the Sahara, often referred to as "Sub-Saharan Africa". Even then, these countries have disparate developmental levels. In particular, South Africa is a standout to which some of the discussions here would not apply. By the same token, some of the discussions in the article may be applicable to countries lying north of the Sahara, often referred to as Arab North-Africa.

6) A. Portugal-Perez and J.S. Wilson, 'Why Trade Facilitation Matters to Africa' (2009) 8 World Trade Review 379-416. The authors computed their figures from COMTRADE data available through the World Integrated Trade Solution (WITS).

7) UNCTAD, UNCTAD Handbook of Statistics 2011 (UN, New York, NY, 2011) 10. The data has Africa's share of exports in 2006 at $3.073 \%$.

8) UNECA, Economic Report on Africa: Developing African Agriculture Through Regional Value Chains (UNECA, Addis-Ababa) 78, available at http://new.uneca.org/Portals/era/2009/ERA2009_ENG_Full. pdf (accessed 2 October 2012).

9) Despite employing a large part of the labour force in many countries, agricultural sectors tend not to produce enough for domestic consumptions, let alone surpluses for exports. The manufacturing sector is often very small, and its products may not meet international standards to support exportation, due perhaps to outdated technology. 
of critical infrastructure and trade logistics, ${ }^{10}$ absence of (or lax) legal and regulatory frameworks, and non-existent, or weak, often highly corrupt, inefficient and ineffective institutions to support production and exports. These may be described as endogenous (or internal) factors, and are attributable to governance and policy ineffectiveness. But there are exogenous (or external) factors too. These may include the design of the world trade system, which some argue disadvantages developing countries in general, ${ }^{11}$ actions by foreign governments (such as agricultural subsidies in advanced economies) that undercut the ability of developing countries to specialise in products for which they may have comparative advantage. ${ }^{12}$ Arguably, endogenous factors also include prescriptive policies foisted on African countries by multilateral development institutions (such as the World Bank and the IMF) and governments of advanced economies, ${ }^{13}$ and international competition. This article discusses only the endogenous factors, though the effects of improvements in those factors, as proposed in this article, are to make African economies internationally competitive - i.e., improvement in an external factor. ${ }^{14}$ The discussions focus on governance. That is, how the deployment of ICT systems can improve governance in general, and trade expansion in particular.

Governance is used here as a broad term encompassing economic management. It is chosen because many debt ridden poor African economies have abundant natural resources (not necessarily of the extractive kind). If managed appropriately, the available resources can be utilised to underpin expansive trade for economic development. Even African countries that may be described as resource poor (or resource scarce) can do better with what they have than they have done so far. Thus the low productivity, abysmal state of infrastructure, and persistent poverty found in most African economies may be attributable to poor governance. ${ }^{15}$ Governance and Africa's development (indeed governance and

\footnotetext{
10) See O. Ajakaiye and M. Ncube, 'Infrastructure and Economic Development in Africa: An Overview' (2010) 19 Journal of African Economies (Supplement 1), i3-i12; C. Calderon and L. Serven, 'Infrastructure and Economic Development in Sub-Saharan Africa' (2010) 19 Journal of African Economies (Supplement 1), i13-i87; K.K. Mbekeani, 'Infrastructure, Trade Expansion and Regional Integration: Global Experience and Lessons for Africa' (2010) 19 Journal of African Economies (Supplement 1), i88-i113.

11) See, e.g., Stiglitz and Carlton, supra note 2, p. v; S. Joseph, Blame it on the WTO? (Oxford University Press, Oxford, 2011).

12) See, e.g., R. Buckley (Ed.), The WTO and the Doha Round: The Challenging Face of World Trade (Kluwer Law International, The Hague, 2003) 1-6.

13) See, A. Noman, K. Botchwey, H. Stein and J.E. Stiglitz (Eds), Good Growth and Governance in Africa: Rethinking Development Strategies (Oxford University Press, Oxford, 2012), 3-47. See, generally, C. Tan, Governance through Development (Routledge, Abingdon, 2011).

14) Examination of the other external factors is beyond the scope of this article, much as they are important. Those factors are the subject of many scholarly writings. In any case, the Asian economies that have been successful with export-led growth have done so despite those external factors.

15) See S. Al-Jurf, 'Good Governance and Transparency: Their Impact on Development' (1999) 9 Transnational Law and Contemporary Problems 193-217, at 198-199; UNECA, Economic Report on Africa: Unleashing Africa's Potential as a Pole of Global Growth (UNECA, Addis-Ababa, 2012) 104-138, available at http://new.uneca.org/Portals/era/2012/ERA2012_ENG_FIN.pdf (accessed on 3 October 2012).
} 
development of developing countries in general) has been the subject of much study and writing, with contrasting views and conclusions. ${ }^{16}$ Factors other than poor governance have also been proffered to explain Africa's economic underperformance. These include unfavourable human geography, ${ }^{17}$ culture, ${ }^{18}$ colonialism and conspiracy of developed economies. ${ }^{19}$ While there may be some validity in the causative effects of each of those other factors, governance deficiencies have been recognised as a critical cause in more recent times. ${ }^{20}$

In relation to exports, for instance, Desta and Hirsch ${ }^{21}$ found that a major impediment to the ability of some seven Eastern African countries to translate their comparative advantage in agricultures, particularly the livestock sector, into a meaningful export-led economic growth is sanitary import requirements in foreign markets and lack of institutional capacity to enable the producers to satisfy

See also World Bank, Sub-Saharan Africa: From Crisis to Sustainable Growth (World Bank, Washington, DC, 1989) 60, where, in explaining Africa's development problems, the Bank stated that 'underlying the litany of Africa's development problems is a crisis of governance'; C. Ciborra and D.D. Navarra, 'Good Governance, Development Theory, and Aid Policy: Risks and Challenges of E-Government in Jordan' (2005) 11(2) Information Technology for Development 141-159.

16) See Noman et al., supra note 13. See also A. Gelb, Windfall Gains: Blessing or Curse? (Oxford University Press, New York, NY, 1988); R. Auty, Resource-Based Industrialization: Sowing the Oil in Eight Developing Countries (Oxford University Press, New York, NY, 1990); J. Sachs and A. Warner, 'The Big Push, Natural Resource Booms and Growth', (1999) 59 Journal of Development Economics 43-76; J. Sachs and F. Rodriguez, 'Why Do Resource-Abundant Economies Grow More Slowly?' (1999) 4 Journal for Economic Growth 277-303; H.J. Chang, Kicking Away the Ladder: Development Strategy in Historical Perspective (Anthem Press, London, 2002); H. Mehlum, K. Moene and R. Torvik, 'Institutions and Resource Curse' (2006) 116 (508) The Economic Journal 1-20; E. Weinthal and P. Luong, 'Combating the Resource Curse: An Alternative Solution to Managing Mineral Wealth', (2006) 4(1) Perspectives on Politics 435453; A. Boschini, J. Pettersson and J. Roine, 'Resource Curse or Not: A Question of Appropriability', (2007) 109 Scandinavian Journal of Economics 593-617; D.S. Go and J. Page, Africa at a Turning Point? (The World Bank, Washington DC, 2008); H.J. Chang, Bad Samaritans: The Myth of Free Trade and the Secrete History of Capitalism (Bloomsbury Press, New York, NY, 2008); C. Brunnschweiler and E. Bulte, 'The Resource Curse Revisited and Revised: A Tale of Paradoxes and Red Herrings' (2008) 55 Journal of Environmental Economics and Management 248-264; C. Brunnschweiler, 'Cursing the Blessings? Natural Resource Abundance, Institutions, and Economic Growth’, (2008) 36 World Development 399-419.

17) See, e.g. , D.S. Landes, The Wealth and Poverty of Nations: Why Are Some So Rich and Others So Poor? (W.W. Norton, New York, NY, 1998).

18) See, e.g. , L.E. Harrison, Who Prospers: How Cultural Values Shape Economic And Political Success (Basic Books, New York, NY, 1992); L.E. Harrison and S.P. Huntington (Eds), Culture Matters: How Values Shape Human Progress (Basic Books, New York, NY, 2000). Contrast with H. de Soto, The Mystery of Capitalism: Why Capitalism Triumphs in the West and Fails Everywhere Else (Random House, New York, NY, 2000), 4.

19) See, e.g., N. Nunn, 'The Long-Term Effects of Africa's Slave Trades' (2008) 123(1) Quarterly Journal of Economics 139-176; N. Nunn, 'Historical Legacies: A Model Linking Africa's Past to its Current Underdevelopment' (2007) 83(1) Journal of Development Economics 157-175.

20) F.N. Botchway, 'Introduction', in F.N. Botchway (Ed.), Natural Resource Investment and Africa's Development (Edward Elgar, Cheltenham, 2011) 1-20, at 6.

21) M.G. Desta and M. Hirsch, 'African Countries in The World Trading System: International Trade, Domestic Institutions and the Role of International Law' (2012) 61 International and Comparative Law Quarterly 127-170. 
the requirements of the prospective importing countries. ${ }^{22}$ Among the institutional weakness factors identified are lax laws and regulation, lack of enforcement of the weak laws and regulations that may exist, corruption, and inadequate skills. ${ }^{23}$ Targeted government policies that would strengthen the capacity of those countries in the agricultural sector to enable exports would be good strategy; it would be 'good governance'. The development of that industry can lead to other economic spin-offs.

This article argues that the deployment of appropriately targeted ICT systems in the form of e-governance can enhance governance and trade expansion, which will in turn improve economic growth and development. It suggests that e-governance, including e-customs, can improve governance generally, and expand international trade specifically. While the general aspects of governance improvements are broader, economy-wide, and may take time to improve, e-customs is specific and more easily and readily attainable. The article is thus divided into four sections, including this introduction. Section 2 discusses issues of good governance, noting that there is no single definition that is universally accepted. It adopts a description that encapsulates a few generally acknowledged elements, namely democracy, rule of law, transparency and accountability, low corruption, and effective and efficient economic management. Section 3 discusses how ICT systems can enhance governance and facilitate trade expansion. Section 4 concludes the article with some observations.

\section{Good Governance}

This part discusses issues of governance, its deficiencies and impact on Africa's economic development generally, and trade expansion specifically. It starts with definitional issues, then manifestations, causes and consequences of the deficiencies. ${ }^{24}$

\subsection{Good Governance Described}

It must be noted at the outset that the concept of 'good governance' is difficult to define succinctly. ${ }^{25}$ The reasons are that the term "is heavily value-laden," 26 and

22) Ibid. The seven countries studied are Djibouti, Eritrea, Ethiopia, Kenya, Somalia, Sudan and Uganda. 23) Ibid.

24) Some of the discussions in this part have been considered in more detail by the author elsewhere. See E.T. Laryea, 'Promoting Good Governance through ICT Systems: Improving Transparency and Reducing Corruption' in R.P. Buckley (Ed.), Debt-for-Development Exchanges: History and new Applications (Cambridge University Press, New York, NY, 2011) 260-295.

25) See, e.g. F.N. Botchway, 'Good Governance: the Old, the New, the Principle and the Elements', (2001) 13 Florida Journal of International Law 160-161 (hereafter, 'Botchway, 'Good Governance'). See also, G. Stoker, 'Governance as Theory: Five Propositions', (1988) 50 International Social Science Journal 17-28; T.G. Weiss, 'Governance, Good Governance and Global Governance: Conceptual and Actual Challenges', (2000) 21(5) Third World Quarterly 795-814.

26) Botchway, 'Good Governance', p. 162. 
can be general in its orientation, admitting multiple elements. ${ }^{27}$ The concept has also not only evolved over time, it has been discussed in different contexts, and given different meanings or emphases in particular contexts. Besides, models held as exemplifying good governance at one time could be exposed to be seriously deficient another time. For instance, before the Global Financial Crisis (GFC), US laws, policies and institutions were held as exemplifying good governance structures. ${ }^{28}$ "Now, most observers would have to admit that there were major deficiencies in both US policies and institutions." 29

Despite the definitional difficulties, a description or the provision of a list of elements for the concept seems to be generally acceptable. ${ }^{30}$ Elements generally accepted include transparency and accountability; low corruption; effective, efficient and equitable management of resources; democracy; and rule of law. ${ }^{31}$ Each of these elements is broad, and hardly amenable to easy or precise definition. What each entails may not only be controversial; it may also be contradictory. ${ }^{32}$ The elements also interrelate greatly, and possibly circuitous. For instance, prevalence of corruption may stem from lack of transparency and accountability, which in turn may be a result of lack of democracy and rule of law, and all of these may lead to ineffective, inefficient and inequitable management of the available resources. Further, the rule of law, particularly technical, individualistic and procedural rights can be used to defeat investigations and prosecutions of corruption. ${ }^{33}$ Thus the rule of law can become a shield behind which perpetrators of corruption can hide to practice the vice, rather than it (the rule of law) being an instrument for preventing corruption. ${ }^{34}$

If, however, the problems with precise meanings are ignored for the moment, and the proposition is accepted that the elements listed above are good for development, then a deficiency in one or more of the listed elements will impact adversely on development. It is not possible to discuss all of the elements in detail, or the possible permutations of deficiencies and their likely effects, in this article. Within the limited space available, this article selects two of the elements for

\footnotetext{
27) Botchway, 'Good Governance', p. 162.

28) T. Franck, 'The New Development: Can American Law and Legal Institutions Help Developing Countries?' (1972) 3 Wisconsin Law Review 770-778; Noman et al. supra note 13, p. 6.

29) Noman et al., supra note 13, pp. 6-7.

30) Botchway, 'Good Governance', supra note 25, p. 161.

31) D. Kaufmann, A. Kraay and A. Mastruzzi, 'Governance Matters III: Governance Indicators for 19962002', Policy Research Working Paper No. 3106 (World Bank, Washington, DC, 2003). See also A. Iimi, 'Escaping from the Resource Curse: Evidence from Botswana and the Rest of the World', (2007) 54(4) IMF Staff Papers 672-673.

32) Botchway cites an example of a policy to provide electric power to a remote and economically depressed part of a country, where it may be equitable for the inhabitants there, but economically inefficient, in the short term at least. See Botchway, 'Good Governance', supra note 25, p. 162.

33) J.T. Gathii, 'Defining the Relationship between Human Rights and Corruption' (2009) 31 University of Pennsylvania Journal of International Law 125, 160-171.

34) See, ibid., pp 160-171, where the author demonstrates how this happened in the Kenyan context.
} 
further discussion: effective, efficient and equitable management of resources (i.e. economic management); and corruption. It presents these two as main deficiencies in African (and for that matter developing) countries that impede not only trade, but development generally.

\subsection{Economic Mismanagement as Governance Deficiency}

\subsubsection{Manifestations of the Deficiency}

Economic mismanagement is a manifestation of poor governance. Economic mismanagement in this context means failure by the managers of an economy, primarily the political leaders, to marshal the available resources in the economy (as well as attract resources from external sources), to the best of uses and for the best possible outcomes for the economy and its peoples. Economic mismanagement then includes: failure to indentify the resources available and/or their potential value; failure to formulate policies and conditions that would facilitate effective and efficient utilisation of the resources; and failure to identify areas of comparative advantages, and to formulate and execute policies for the development of those areas in a manner that would lead to sustained growth and benefits.

The failures listed above lead to inabilities of governments to generate optimal incomes (or returns) from the resources with which the economy may be endowed. But worse, wastage of the little resources that the governments obtain is also quite common. It is not uncommon for African governments to build presidential palaces and other edifices instead of basic public and productive infrastructure (such as roads, schools, hospitals, water and sanitation, robust governance institutions and technology). To give an example, a Ghanaian government decided to build, in 2005, a new presidential palace, later named 'Jubilee House' ${ }^{35}$ following public criticisms. The project cost hundreds of millions of borrowed dollars, excluding the value of the land, which was already owned by government. The 'palace' was built while most public infrastructure is in a deplorable state. For instance, there is no ultimate referral hospital in the country. So, when politicians are sick, they are flown abroad (mostly to the UK, US and South Africa) at huge cost to the citizenry. ${ }^{36}$ Further, hundreds of millions of borrowed dollars was lavished on celebrations of Ghana's golden jubilee in 2007, and this occurred at same time as

35) The 'Jubilee House' referred to Ghana's 50th Anniversary of Independence from the British on 6 March 1957, the golden jubilee, falling on 6 March 2007).

36) Apart from the obvious unfairness of such a practice on the ordinary citizen (the politician gets to be transported to a developed country for treatment at the expense of the ordinary citizen, but the ordinary citizen has to make do with what is available locally), the practice seems to ignore the fact that timely diagnosis and treatment can be critical in health issues. Precious time may be lost where patients have to be flown for hours to hospitals in foreign countries for treatment. Thus, the political elites are exposed to serious risks by relying on treatment abroad instead of building and equipping at least one ultimate referral hospital in the country for all. 
Ghana was issuing sovereign bonds to the tune of US\$750 million on the international capital market, in September 2007. ${ }^{37}$ The economic consequences of borrowing for unproductive ventures are well documented. ${ }^{38}$ It leads to financial and economic crises, as money often have to be found from sources other than the venture of spending to service and repay the loan. ${ }^{39}$

\subsubsection{Causes of Economic Managements}

The causes of the failures and wasteful practices mentioned in the preceding section are obviously complex. Each possible cause can be the subject of several theses in the fields of economics, political economy, and law, among others. The causes have been the subjects of several studies, some of which have been referred to earlier in this article. They have spun countless publications by eminent scholars. This article does not intend to duplicate those voluminous materials. ${ }^{40}$ It simply summarises the mismanagement as stemming from incompetence, bad advice, poor judgement, ignorance and, some may argue, social constraints. ${ }^{41}$

Obviously many countries and regions around the world have been able to manage their resources (and extract better value from those resources for the benefit of their citizens) far better than most African economies have done. Various studies have offered various solutions to the African problems. This article suggests a solution to aspects of the problems; it suggests, in Part 3, how ICT can help enhance management and trade expansion. It takes a micro level focus on trade expansion, though the factors that detract from the trade expansion effort are broader, i.e., macro, by nature. The next section deals with one such factor, corruption.

\subsection{Corruption as Governance Deficiency}

It is common for corruption to be subsumed under economic mismanagement, and rightfully so. Broadly viewed, corruption leads to inefficient allocation (i.e.

\footnotetext{
37) See, J. Chung, 'Ghana Makes International Bond Debut', Financial Times, 28 September 2007, available at http://www.ft.com/cms/s/0/7eea57d4-6d60-11dc-ab19-0000779fd2ac.html (accessed 31 July 2012); L. Adoma Yeboah, 'Ghana's Eurobond Wins Award' (Monday, December 31, 2007), available at http://lucyadoma.blogspot.com/2007/12/ghana-eurobond-wins-award.html (accessed 31 July 2012).

38) See, e.g., R. Buckley, 'A Tale of Two Crises: The Search for the Enduring Reforms of the International Financial System' (2001) 6 UCLA J. of International Law \& Foreign Affairs 1-43, at 18-20.

39) Ibid.

40) One of the most recent and accessible volume this author can recommend is the edited volume by Noman et al, which was referred to earlier in this paper. See Noman et al., supra note 13.

41) Social constraints may broadly be described as prevailing social conditions that inhibit government from implementing economically prudent, but socially tough, reforms that may disturb existing cohesion within the country. On mismanagement stemming from social constraints, see J. Ritzen, W. Easterly and M. Woolcock, 'On "Good" Politicians and "Bad" Policies: Social Cohesion, Institutions, and Growth' (2000) World Bank Policy Research Working Paper No. 2448, available at http://econ.worldbank.org/external/ default/main?pagePK=64165259\&piPK=64165421\&theSitePK=469372\&menuPK=64216926\&entity ID=000094946_0009200531267. (accessed on 31 July 2012).
} 
mismanagement) of resources. But the context of mismanagement discussed in the previous section refers to inefficient allocation of resources actuated by factors other than corruption. That is, allocation of resources to sub-optimal uses or for sub-optimal returns due to incompetence, bad advice, poor judgement, ignorance or social constraints. Here corruption is treated separately.

\subsubsection{Definitional Issues with Corruption}

The term "corruption" is used in several contexts to describe a myriad of situations or actions. In this article, one of the many conventional definitions is adopted. That is, the "misuse of public power for private or political gain or profit". ${ }^{42}$ This definition captures most, if not all, activities usually considered as corrupt (and illegal in most countries), such as taking bribes, embezzlement, fraud, misappropriation of public resources for private use, nepotism and cronyism. These form the largest part of corruption, and are the most destructive to developing economies. Corruption, of course, also exists within the private sector. ${ }^{43}$ Zimiring and Johnson ${ }^{44}$ cite as an example of abuse of private power an estate agent who sells property to a friend for less than its market price.

\subsubsection{Kinds of Corruption}

There are various kinds of corruption. However, due to space limitation, only three kinds are mentioned here, namely: (1) bribery in the provision of public goods and services; (2) bribery in the judicial system; and (3) misappropriation of public resource.

\subsubsection{Bribery in the Provision of Public Goods and Services}

Bribe extraction by providers of government services is a major problem in African countries. It is pervasive, and damaging. Unfortunately, individuals and entities have to deal with government departments at various times (for instance, for mandatory registrations; to obtain approvals, licences, and permits from regulatory bodies). Public officials often take advantage of their position to extract bribes, due to weaknesses in the old fashioned systems under which they operate. Their practices can have detrimental consequences, such as increase transaction costs for business; hinder investments, and production for domestic use and exports; hider job creation; and adversely affect economic growth and development.

\footnotetext{
42) A. Nwabuzor, 'Corruption and Development: New Initiatives in Economic Openness and Strengthened Rule of Law' (2005) 59 Journal of Business Ethics 121-138.

43) See, e.g., V. Tanzi, Corruption Around the World: Causes, Consequences, Scope, and Cures, IMF Working Paper (IMF, Washington D.C, 1998) 8, available at http://www.imf.org/external/pubs/ft/wp/wp9863. pdf (accessed on 31 July 2010); F.E. Zimring and D.T. Johnson, 'On the Comparative Study of Corruption' (2005) 45(6) British Journal of Criminology 793-809.

44) Zimiring and Johnson, ibid., pp. 799-800.
} 


\subsubsection{Bribery in the Judicial System}

The judicial process can be subject to three forms of corruption. The first two forms occur in matters between private individuals or firms, on the one hand, and government on the other hand. The first is usually present where the judiciary is not independent, and results in biased (or illegal) rulings in favour of government, though there may not be direct bribes paid to members of the judiciary.

The second form manifests in situations where private individuals pay bribes to judicial officers (often together with representatives of governments) in order to avoid or minimise sanctions for breaches of the law, including tax evasion, environmental damage, infringements of workers' rights and embezzlement.

The third form is encountered in matters between private individuals or firms, and involves the making of illegal rulings in favour of one party in return for favours from that party, usually monetary payments.

All forms of bribery in a judicial system undermines the rule of law, diminishes the enjoyment and enforcement of rights and respect for and observance of obligations. They undermine trust and confidence in the system, which leads to costly and inefficient responses by businesses. This, in turn, increases trade transaction costs.

\subsubsection{Misappropriation of Public Resources}

This type of corruption includes embezzlement of government funds, theft of other public resources, and civil service fraud. It is rampant in many African countries. It results in loss of revenue and assets to the state, and consequent lack of resources for legitimate government business, such as investment in infrastructure and institutions to support trade and development.

\subsubsection{Causes of Corruption}

Various explanations have been given for the prevalence, and magnitude, of corruption in African and other developing economies..$^{45}$ These, particularly the conditions that enable corruption to prevail, include: poverty, ${ }^{46}$ limited economic freedom,,${ }^{47}$ absence of effective rule of law, ${ }^{48}$ absence of democracy, ${ }^{49}$ and absence

\footnotetext{
45) Undoubtedly, there is some degree of corruption in every country, but the magnitude, degree, incidence or pervasiveness vary greatly among countries. See, e.g., S. Tolotti, K. Wise and P. Noble, 'Nations United in Sleaze' (1996) 43 World Press Review 18-19; F. Anechiarico and J.B. Jacobs, The Pursuit of Absolute Integrity: How Corruption Control Makes Government Ineffective (University of Chicago Press, Chicago, IL, 1996) 9.

46) See, e.g., Nwabuzor, supra note 42.

47) A.I. Eiras, 'Make The Rule of Law A Necessary Condition For The Millennium Challenge Account' (2003) available at http://www.heritage.org/Research/Reports/2003/03/Make-the-Rule-of-Law-a-Necessary-Condition (accessed on 31 July 2012).

48) Eiras, ibid.

49) It must be noted that democracy is not simply about holding elections; it entails far more than that. Organising elections for the sake of it, without freedom and fairness, does not meet the most basic element of democracy, and would not produce the positive outcomes of democracy alluded to in this paragraph.
} 
of transparency and accountability. ${ }^{50}$ That these factors cause corruption is contentious. It is not feasible to examine in detail the debates regarding the causes of, or conditions conducive to, corruption. Only a few, particularly those that enable corruption to prevail and which affects trade expansion, are expanded below.

\subsubsection{Limited Economic Freedom}

The absence of economic freedom is said to encourage corruption. ${ }^{51}$ Economic freedom is defined as "the absence of government constraint or coercion on production, distribution and consumption of goods and services that are beyond the extent necessary for citizens to maintain and protect liberty itself." ${ }^{2} 2$ The absence of economic freedom means the government owns and runs much of the national economy, with attendant inefficiencies. Those in charge wield enormous power over public assets, which they use to profit themselves. This means the focus of the managers, those in charge, is not to grow production effectively and efficiently and to seek markets and profits for the benefit of the economy as a whole; their focus is self enrichment at the expense of all else.

Many African countries seem to suffer from this problem. Soon after gaining independence, after the mass decolonisation in the 1960s, many of the countries embarked on state own enterprises (SOEs) as the main vehicles for economic production and development. Most failed miserably, impoverishing the countries and leaving only the managers rich in the end.

Of course simply because an economic entity is government owned does not necessarily mean those in charge should or would be corrupt, inefficient, ineffective, and the entity will ultimately fail. There are state owned enterprises in the developed world that have operated profitably. For instance, before its partial privatisation by the Australian federal government, Telstra, the nation's biggest telecom entity, operated efficiently and profitably, contributing to the federal government's revenue stream.

Further, China, which is arguably the most export-driven developing country in the last two decades, has done so on the back of large state controls and involvement in commercial enterprise. However, it is equally arguable that China's phenomenal growth in exports, and in its economy in general, have coincided with its economic openness and liberalisation relative to the preceding decades of lower growth.

\subsubsection{Absence of Effective Rule of Law}

The concept of rule of law lacks a precise definition, but is understood to cover ideals that subject the exercise of powers held by leaders within certain constraints

50) D. Kaufman, "Myths and Realities of Governance and Corruption", in World Economic Forum (ed), Global Competitiveness Report 2005-2006 (Palgrave Macmillan, Basingstoke, 2005) 81-98.

51) Eiras, supra note 47.

52) Nwabuzor, supra note 42, p. 125. 
provided by a framework of public norms. ${ }^{53}$ It encompasses three elements: the supremacy of the law and absence of arbitrariness; equality before the law; and, constitutional law as part of the ordinary law of the land. ${ }^{54}$

Rule of law ensures that political power is not abused. Without the rule of law, there would be no mechanism to stop private abuse and public mismanagement. ${ }^{55}$ In an environment of very weak rule of law, national assets are stolen by elites, often with impunity. People take matters into their own hands, using whatever means they could, including corruption, to advance their self interest. It also means corrupt practices, if they constitute crime under the nation's laws (and corruption is illegal in most, if not all, jurisdictions), go largely unpunished, which then reinforces the practice.

This then may help explain the success of SOEs in developed economies (such as Telstra in Australia prior to its partial privatisation in the late 1990s) and the failed ones in Africa. However, it cannot explain China's successes because China is not noted for its rule of law.

\subsubsection{Absence of Democracy}

As the saying goes, "power corrupts, and absolute power corrupts absolutely" ${ }^{56}$ In autocratic jurisdictions, where the power of the leadership is effectively subject to little or no limitation, abuses are most likely to occur. It is entirely possible for there to be a benevolent dictator who, despite any absolute powers it may wield, is incorrupt and to govern with the utmost interest of the governed at the fore. However, experience shows that such situations are rare. Dictatorial regimes have tended to be most corrupt. Thus democracy helps to control corruption.

But what is democracy? Any particular effort to define democracy attracts criticisms. ${ }^{57}$ This may be due to its overtly political character. Perhaps the easiest definition is that which takes democracy as a form of governance based on some degree of popular sovereignty and collective decision making. ${ }^{58}$ Democracy may be appreciated from procedural, institutional and social view points. Procedurally, democracy encapsulates the legitimacy of the opposition, protection of freedoms

\footnotetext{
53) J. Waldron, 'The Concept and the Rule of Law' (2008) 43 Georgia Law Review 1-62, pp. 6-9.

54) A.V. Dicey, An Introduction to the Study of the Law of the Constitution, 10th edn (Macmillan, London, 1959) 193-194. See also I. Saunders and K. Le Roy (Eds), The Rule of Law (The Federation Press, Sydney, NSW, 2003) 5.

55) Eiras, supra note 47.

56) This quotation is attributed to John Emerich Edward Dalberg Acton (1834-1902), a British historian and moralist, who was otherwise known simply as Lord Acton, in a letter to Bishop Mandell Creighton in 1887. See http://www.phrases.org.uk/meanings/288200.html (accessed on 31 July 2012).

57) M. Saward, 'Democratic Theories and Indices of Democratization' in D Beetham, (Ed.) Defining and Measuring Democracy (Sage, London, 1994) 6-8.

58) T. Landman, 'Democracy Analysis' in International IDEA, Ten Years of Supporting Democracy Worldwide (International IDEA, Stockholm, 2005) 20.
} 
(of expression and association), free and fair elections, universal suffrage, and equity. ${ }^{59}$ Subjecting the mandate of the political leadership to the citizenry means they (the political leaders) have to be weary of corruption, among other things. If they are not, and are considered to be corrupt, they would be voted out of government. Consequently, it is not uncommon to see political opposition in African countries portraying incumbents as corrupt and promising anti-corruption if voted into office. ${ }^{60}$ Such campaigns are almost always popular. ${ }^{61}$

Here again, there are several countries, such as China, whose governance systems are very different from the western notions of democracy but which have had sustain high trade expansion and economic growth. By contrast, India is generally democratic, but has high levels of corruption, and its economy has not performed as well as China's has done in the last two decades. For instance, ignoring all the possible flaws and criticisms that can be leveled against the corruption indices, India ranks 95th (with a score of 3.1 out of a possible 10) on the Transparency International's Corruption Perceptions Index 2011, while China ranks 75th (with a score of 3.6). ${ }^{62}$ And, according to World Bank data, China's economic growth was higher than India's in fourteen out of fifteen years from 1997 to $2011 .^{63}$

\subsubsection{Absence of Transparency and Accountability}

Corruption and bribery typically operate, and thrive, in opacity. ${ }^{64}$ Transparency in a system that enables the citizenry to know what, why, how and by whom

\footnotetext{
59) It should be noted that the list is not exhaustive. There is no complete set of democratic procedures and there is no sufficient set of elements for democracy. See, generally, R. Dahl, Polyarchy: Participation and Opposition (Yale University Press, New Haven, CT, 1971).

60) Examples can be given of Ghana, where in the lead up to the 2000 elections, the then main opposition party (the New Patriotic Party (NPP)) campaigned mainly on corruption of the incumbent and promised a "Zero tolerance of corruption" if voted into power. And they succeeded. For more information on this, see 'The Challenges Facing Anti-Corruption in Ghana', (December 2009) Ghana Integrity Initiative Quarterly Newsletter (GII Alert 23) 9, available at http://www.tighana.org/newsletters/GII_ALERT_23 .pdf (accessed on 31 July 2012).

61) It must be noted that democracy is not simply about holding elections; it entails far more than that. Organising elections for the sake of it, without freedom and fairness, does not meet the most basic element of democracy, and would not produce the positive outcomes of democracy alluded to in this paragraph.

62) Transparency International, Corruption Perceptions Index 2011, available at http://cpi.transparency. org/cpi2011/results/ (accessed 1 October 2012). Transparency International is an international nongovernmental organization that has been at the forefront of fighting corruption internationally and raising public awareness of the problem. Originally founded in Germany in May 1993 as a not-for-profit organization, it is now organized as a group of some 100 national chapters across the globe, with an international secretariat in Berlin, Germany. It has published an annual Corruption Perceptions Index (CPI) since 1995.

63) See The World Bank, GDP Growth (Annual \%), available at http://data.worldbank.org/indicator/ NY.GDP.MKTP.KD.ZG (accessed on 2 October 2012). Apart from 1999, where India's economy grew by $8.5 \%$ as opposed to China's $7.6 \%$, China grew mach higher than India for the rest of the fifteen years.

64) Kaufman, supra note 50, p. 83.
} 
decisions are taken, appointments are made, and resources are allocated reduces corruption and engenders trust and confidence in the system.

Accountability, in this context, is an available framework to subject actions and decisions of public officials to oversight, and ensures that formulation of government initiatives is not only scrutinized but that those implemented meet their planned objectives. It also ensures that government responds to the needs of the citizenry, and contributes to reduce corruption.

Accountability and transparency, therefore, impose checks on governmental action, particularly resource allocation, development and use. They also allow the citizenry to contribute to policy formulation, execution and evaluation. These lead to better use of national resources; better identification of areas of comparative advantage, informed investment choices, more efficient exploitation and production in the economy. These can then enhance trade.

\subsubsection{Consequences of Corruption}

There are many ways by which corruption, arguably, militate against a nation's ability to utilise its resources for the development and benefit of its peoples. Evidence from cross-country empirical studies has confirmed the negative impact of corruption on institutions, investments, growth and productivity, policy processes, property rights, and consequently overall development. ${ }^{65}$ In particular, corruption wastes national resources, as it leads to a diversion of economic resources away from legitimate uses. It leads to sub-optimal resource allocation, ${ }^{66}$ which makes the economy uncompetitive in the global market place.

Corruption undermines the quality of goods and services produced in a given economy, by both private and government entities. ${ }^{67}$ For instance, private entities may pay bribes to avoid the enforcement of standards against them, resulting in their production of sub-standard products. Public officials in government departments may issue certificates of dubious quality upon payment of bribes to them. As noted in the study by Desta and Hirsch, referred to earlier in this article, ${ }^{68}$ corruption undermines the quality of certificates issued by regulatory bodies in the studied countries, which in turn undermines the ability to exports products in which the countries have clear comparative advantage. ${ }^{69}$

Corruption also discourages investment in an economy. A high incidence of corruption increases transaction cost for business, undermines trust and confidence in the security of investment, and therefore discourages investment

\footnotetext{
65) A.R.ose-Ackerman, Corruption and Government: Causes, Consequences, and Reform (Cambridge University Press, Cambridge, 1999).

66) N.H. Jacoby, P. Nehemkis and R. Eells, Bribery and Extortion in World Business: A Study of Corporate Political Payments Abroad (Macmillan, New York, NY, 1977) 142.

67) Ibid.

68) Desta and Hirsch, supra note 21.

69) Desta and Hirsch, supra note 21.
} 
from both domestic and foreign sources. ${ }^{70}$ It is not uncommon for residents in developing countries with high incidence of corruption to invest their capital (often obtained through corrupt activities) abroad. It means domestic capital formation is undermined. Investment, particularly foreign direct investment (FDI), is very important for the expansion of production for exports. This is because most African economies lack the necessary capital and technology for development of their resources. Where corruption discourages FDI inflow to an economy, the ability of that economy to expand its exports is hampered.

When investments come in, corrupt public officials may, for private benefits, grant to the investors contracts that are one-sided in favour of the investors, depriving their country the necessary benefits. The primary object of the investor is to procure profits, obtaining the maximum possible risk-adjusted return on its investment over the life of the investment. Normally, the broad primary objective of the host State is the general public interest of economic development, translating into expectations of maximum revenue from the exploited resources, job creation (direct and indirect), transfer of technology to the host State, increased capital stock, and spin-off of new and allied industries. History has shown, however, that the interest of most public officials in African countries is often private benefit, not public interest of economic development. They "ensure that the rest of the population receives almost no benefit from the resources with which their countries have been abundantly endowed." ${ }^{11}$ This, then, deprives the economies of the typical expected economic outcome of the investments for the nations.

Corruption's effect of lack of investment, sub-optimal allocation of resource, waste of recourses, selling short the countries resources result is the country's inability to provide the infrastructure and products necessary for exports. Not only that, corruption generally detracts from the developmental efforts of any nation, as it can lead to apathy among the citizenry, undermining the desire to work hard, create and innovate. As Frisch put it, corruption can kill "the development spirit - nothing is as destructive to a society as the rush to quick and easy money which makes fools of those who can work honestly and constructively."72

It is not suggested here, however, that production, growth, trade expansion and development cannot occur in African economies, or other economies for that matter, if there is corruption. As noted earlier, there is corruption in every

\footnotetext{
70) S. Pillay, 'Corruption - The Challenge to Good Governance: A South African Perspective' (2004) 17(7) International Journal of Public Sector Management 586-605; Nwabuzor, supra note 42, pp. 129-130.

${ }^{71)}$ E. Duruigbo, 'Permanent Sovereignty and Peoples' Ownership of Natural Resources in International Law' (2006) 38 George Washington International Law Review 33-100, p. 34.

72) D. Frisch, 'Effects of Corruption on Development' in A. Aderinwale (Ed.), Corruption, Democracy and Human Rights in Southern Africa, Summary Report of a Seminar organised jointly by Africa Leadership Forum and Transparency International, in Pretoria, South Africa, 31 July-2 August 1995, Africa Leadership Forum, Cotonou (1995) 92-97, p. 96, available at http://www.africaleadership.org/rc/ corruption,democracy\%20\&\%20human\%20rights\%20southern\%20Africa.pdf (accessed 20 June 2012).
} 
economy. ${ }^{73}$ In fact, some of the countries with the fastest growing economies and high volumes of exports on the globe currently do not rank highly on the corruption indices. For instance, China and Brazil rank 75th and 73rd respectively on the Transparency International's Corruption Perceptions Index 2011, while Ghana ranks 69th (jointly with Italy, FYR Macedonia and Samoa). ${ }^{74}$ Admittedly there are serious flaws in the index, but the point here is that corruption in an economy is not the end. It may be that the critical issue is for economies to identify their particular sectors of strengths in the context of the global economy, and 'govern' those sectors well.

Nonetheless, a low-corruption overall has tangible benefits for an economy. It reduces transactions costs, enhances confidence in that economy, helps attract investments, and makes it competitive. The next session, therefore turns to how ICT be used to reduce corruption and enhance governance generally.

\section{How ICT Can Enhance Governance and Trade Expansion}

It has, thus far, been argued that governance deficiencies are a critical cause of the inability of African economies to utilise their resources effectively for economic development. The discussion has focused on economic mismanagement and corruption as debilitating manifestations of deficient governance. This is generally acknowledged, by the multilateral international development institutions, aid agencies, international civil society, and academics. ${ }^{75}$ This part outlines how the deployment of ICT systems, in the form of e-governance, can help improve governance and trade expansion. This is not to suggest that ICT has never been considered as an instrument for improving governance; it has. ${ }^{76}$ The discussion here focuses not only on the improvements in governance generally, but also on trade expansion specifically.

\footnotetext{
73) See text around footnote 45.

74) Transparency International, Corruption Perceptions Index 2011, supra note 62.

75) See, e.g. , UN, Monterrey Consensus on Financing for Development (2002), above, note 27, paras 11-17, available at http://www.un.org/esa/ffd/monterrey/MonterreyConsensus.pdf (accessed on 31 July 2012) (The Monterrey Consensus is a document adopted at the United Nations International Conference on Financing for Development, held in Monterrey, Mexico, 18-22 March 2002. Participants included over fifty Heads of State, more than two-hundred Ministers of Finance, Foreign Affairs, Development and Trade, the Heads of the United Nations, the International Monetary Fund (IMF), the World Bank and the World Trade Organization (WTO), and prominent business and civil society leaders and other stakeholders). See also, UN, Financing for Development: Building on Monterrey (2002), available at http://www. un.org/esa/ffd/documents/Building\%20on\%20Monterrey.pdf (accessed on 31 July 2012); UN Public Administration Programme, United Nations E-Government Survey 2010 (2010) 1, available at http:// www2.unpan.org/egovkb/global_reports/10report.htm (accessed on 31 July 2012).

76) Salbu, for instance, argued over a decade ago, that global diffusion of information technology via the internet has the potential to promote transparency and democracy. See S.R. Salbu, 'Information Technology in The War Against International Bribery and Corruption: The Next Frontier of Institutional Reform' (2001) 38 Harvard J. on Legislation 67-102, at 89-102.
} 


\subsection{Definition of E-Governance}

E-governance, like many of the terms or concepts already discussed, is difficult to define in a manner that is universally acceptable. Several definitions of the term exist in the literature. ${ }^{77}$ The focus of the definition may simply be on ICT-enabled governance or ICT for governance transformation, in some cases extending to engagement and participation in governance by citizens. The definition adopted here is that it is the use of ICT tools to create a transparent, efficient and effective interaction between government and citizens (G2C), government and businesses (G2B) and between government departments (G2G) to enhance government service delivery and to achieve better governance.

\subsection{The Potential of E-governance to Enhance Governance in General}

E-governance is a potential tool for improving governance in African countries, combating corruption and enhancing economic growth. ${ }^{78}$ In terms of combating corruption, the provision of public goods and services, including approval for investments, licences, and granting of permits for various activities, is a major avenue for predation by bureaucrats. From the public's perspective, they often do not know the required processes and requirements, timelines within which processes should be expected to be completed (often there is none), and the chain of responsibility within the relevant government department. On the other hand, appropriate records are not maintained by government departments, no or little audits are carried out, and bureaucrats have unnecessarily wide discretion. These combine to provide perfect conditions for bribe extraction, as public officials are able to frustrate users into bribe payment. The system leaves users at the mercy of bureaucrats.

77) These include "the use of ICTs, and particularly the Internet, as a tool to achieve better government," (OECD, "The e-Government Imperative: Main Findings", (2003) OECD Policy Brief 1, available at http://www.oecd.org/dataoecd/60/60/2502539.pdf (accessed on 31 July 2012); and "the use of information and communication technology (ICT) to promote more efficient and cost-effective government, more convenient government services, greater public access to information, and more government accountability to citizens." (C.G. Wescott, 'E-government to combat corruption in the Asia Pacific Region', paper presented at the 11th International Anti-Corruption Conference, Seoul, South Korea, 25-28 May 2003) 1, available at http://www.adb.org/Governance/egovernment_corruption.pdf (accessed on 31 July 2012).

78) See, e.g., T.B. Andersen, 'E-Government as an Anti-Corruption Strategy' (2009) 21 Information Economics and Policy 201-210; V. Pinilla, L. Torres and S. Royo, 'Is E-Government Leading to More Accountable and Transparent Local Governments? An Overall View' (2010) 26(1) Financial Accountability \& Management 3-20; UN Public Administration Programme, United Nations E-Government Survey 2010 (2010) 1, available at http://www2.unpan.org/egovkb/global_reports/10report.htm (accessed on 31 July 2012). See also S. Bhatnnagar and C. Apikul, 'Fighting Corruption with e-Government Applications' (2006) APDIP e-Note 8, at 1, available at http://www.apdip.net/apdipenote/8.pdf (accessed on 31 July 2012), arguing that "a well-planned e-government strategy can make leaps into building a more efficient, accountable and transparent government. If planned with representation from key stakeholders, e-government applications can rebuild citizen trust in government, promote economic growth by improving interface with business, and empower citizens to participate in advancing good governance." 
E-governance can eliminate the conditions conducive to bribe extractions. To do so, first, the exact processes and required documents should be published both in print and online. This will give users prior knowledge of the processes to follow. Second, realistic timelines should also pre-published to enable users to know when to expect the processes to be completed, and allow them to plan appropriately. Publishing timelines would also put pressure on the relevant public officials of the service provider to act, as reasons would have to be given for not meeting published schedules. It also provides performance indicators by which assessments and audits can be carried out. Third, the chain of responsibility within the service provider's department should be outlined. In particular, avenues for enquiry and lodgement of complaints should be clearly outlined, together with timelines within which a response to enquiries or complaints can be expected. Fourth, to the extent possible, and this would be the case for most services, the application, monitoring and enquiries should be offered online. Fifth, service providers should be required to maintain appropriate records. This would be easier and cheaper in an online environment, as recording can be automated. Sixth, there should be regular audits, and complaints by users who are not satisfied with the services they receive should be investigated promptly, and breaches sanctioned swiftly.

If appropriately implemented, e-governance applications would not only diminish the opportunities for corruption, they would make public administration more transparent and efficient. They will also make officials within the relevant government departments more accountable and responsible, and afford the public improved services. The improved services may engender patriotism and public support, all of which would not only feedback into governance enhancement, but also enhanced economic environment, economic activity, economic growth and development.

There are proven cases of trialled e-governance projects in developing countries yielding such benefits. Examples are the Seoul Metropolitan Government (SMG) ${ }^{79}$ the Bhoomi Project in India, ${ }^{80}$ the Gujarat Border Checkposts project, also in India, ${ }^{81}$ Ghana's GCNet, ${ }^{82}$ and projects in Senegal and Uganda. ${ }^{83}$ Wide ranging studies in other jurisdictions confirm such benefits. ${ }^{84}$ Thus, the potential

\footnotetext{
79) Y.H. Cho and B.-D. Choi, 'E-Government to Combat Corruption: The Case of Seoul Metropolitan Government' (2005) 27(10) International Journal of Public Administration 719-735.

80) Digitisation of Land Records: Bhoomi Project (available at http://www.it.iitb.ac.in/ prathabk/egovernance/egov_success_stories_bhoomi.html).

81) Centre for Electronic Governance Indian Institute of Management, Ahmedabad, Computerized Interstate Check Posts of Gujarat State, India: A Cost Benefit Evaluation Study (November 2002) http://www1 .worldbank.org/publicsector/bnpp/Gujarat.PDF (accessed 20 November 2011).

${ }^{82)}$ L.D. Wulf and J.B. Sokol (Eds), Customs Modernization Initiatives: Case Studies (The World Bank, Washington DC, 2004) 19-32.

83) G.C. Misuraca, E-Governance in Africa: From Theory to Action: A Handbook on ICTs for Local Governance (Africa World Press, Trenton, NJ, 2007).

${ }^{84)}$ Andersen, supra note 78 , p. 201, where the author's conclusion followed a detailed study of some 149 countries.
} 
for ICT application tools to enhance economic management and development is significant.

\subsection{The Potential of Paperless Customs for Trade Expansion}

E-customs is a form of G2B e-governance. It is a system by which the medium of interaction between businesses and customs, including the processes for submission, issuance, transmission and receipt of documents covering exports and imports are done electronically, instead of through paper medium. E-customs offers substantial benefits to all entities. ${ }^{85}$ These include increased economic activity, enhanced competitiveness, reduced transaction costs, reduced corruption within customs (and its associated ills), increased revenues for government, and increased (capital) investments. These are discussed below.

\subsubsection{Enhanced Competitiveness}

Deficiencies in trade logistics are a major cause of lack of competitiveness of many African countries. ${ }^{86}$ Trade logistics have become increasingly important to trade performance of economies because of changes in the nature of international trade in recent years. The modern trend of production and distribution, referred to as "trade in tasks", is a production process whereby various aspects are decomposed into a series of steps or tasks, with different steps undertaken in different countries. ${ }^{87}$ This relies on efficient and fast movement of goods across borders, be they intermediate or finished.

E-customs processes are critical to such task-based production methods, as they remove the delays and costs associated with paper-based systems. ${ }^{88}$ Paper clearance processes have long been found to be slow and costly. ${ }^{89}$ For instance, a 2004 World Bank report estimated that African countries take an average of

\footnotetext{
85) United Nations, 'A Roadmap Towards Paperless Trade' in R. Shastri, Paperless International Trade: An Introduction (ICFAI University Press, Hyderabad. 2006) 107.

86) In simple terms, 'Trade Logistics' covers the equipment and processes involved in moving inputs to the places of production (say, factories) and goods from the place of production to markets or users.

87) N. Krafft and J. Page, 'Trade Logistics: AGOA'S New Frontier', in E. Asmah, S. Karingi, M. Kimenyi, N. Krafft, Z. Lewis, N. Moyo, J. Mutenyo, L. Paez, J. Page, M. Paulos, E. Suruma and O. Taiwo, AGOA AT 10: Challenges and Prospects for US-African Trade and Investment Relations (2010) 22-25, p. 23 (available at http://www.brookings.edu/ /media/Files/rc/reports/2010/07_agoa_africa/07_agoa_africa .pdf (accessed on 15 July 2012).

88) United Nations, "A Roadmap towards Paperless Trade", supra note 85, p. 113.

89) See, Department of Foreign Affairs and Trade, Australia (DFAT), and the Chinese Ministry of Foreign Trade and Economic Cooperation, Paperless Trading: Benefits to APEC (2001) 3, available at http://www .dfat.gov.au/publications/paperless/index.html (accessed on 15 July 2012) (hereafter "APEC Paperless Trade Report").
} 
10.1 days to clear sea cargo though customs, compared to 2.1 days in OECD countries..$^{90}$ Other studies have confirmed such disparities. ${ }^{91}$

Clearance delays lead to interruptions that add to the trade transaction costs (TTCs) for business and cost of end products. ${ }^{92}$ They also lead to inefficient use of already inadequate port space and facilities. Not surprisingly, Africa has one of the highest ratios of trade related transportation costs to value in the world. International "transport costs faced by African countries are almost twice as high as the world average: $12.6 \%$ compared to $6.1 \%$ for the world average." 93

E-customs saves time and the costs associated with delays. This is because it is amenable to automation, lodgement of documentation can be done remotely and at anytime, and transmission of information is fast, virtually instantaneous. The resultant savings enhance the competitiveness of products from the implementing economy. For instance, in a case study on manufacturing in Madagascar, it was estimated that "reducing clearance times to one day, as is the case in some East Asian countries, would have the same effect as a three to five percent cost savings." ${ }^{4}$

\subsubsection{Increased Revenues for Government}

E-customs often lead to increases in tax revenues accruable to government from international trading activities. This is the result of two things. First, paperless customs are more efficient, meaning reduced administration cost, and reduced tax evasion. Second, and perhaps more importantly, e-customs reduces customs

\footnotetext{
90) The World Bank, Global Economic Prospects 2004: Realizing the Development Promise of the Doha Agenda (The World Bank, Washington, DC, 2004) 185), figure 5.1, available at http://siteresources. worldbank.org/INTRGEP2004/Resources/gep2004fulltext.pdf (accessed on 15 July 2012), (hereafter, 'The World Bank, Global Economic Prospects 2004').

91) B. Eiffert and V. Ramachandran, 'Competitiveness and Private Sector Development in Africa: Cross Country Evidence from the World Bank's Investment Climate Data' (Paper presented at the Asia-Africa Trade and Investment Conference, Tokyo, 1-2 November 2004), available at http://www-wds.worldbank.org/external/default/WDSContentServer/WDSP/IB/2005/09/29/000090341_20050929104451/ Rendered/PDF/336650ENGLISH0AFR0Competitiveness.pdf (accessed 2 October 2012).

92) See, e.g., M. Engman, 'The Economic Impact of Trade Facilitation' in OECD, Overcoming Border Bottlenecks: The Costs and Benefits of Trade Facilitation (OECD, 2009) 81-112, available at http://ebookee. org/Overcoming-Border-Bottlenecks-The-Costs-and-Benefits-of-Trade-Facilitation_443721.html (accessed 15 July 2012) (hereafter, 'OECD, Overcoming Border Bottlenecks').

93) W. Naudé and M. Matthee, 'The Significance of Transport Costs in Africa' (2007) 5 United Nations University Policy Brief 2.

94) O. Cadot and J. Nasir, 'Incentives and Obstacles to Growth: Lessons from Manufacturing Case Studies in Madagascar', Regional Program for Enterprise Development (RPED), (The World Bank, Washington. DC, 2001) 11, available at http://siteresources.worldbank.org/EXTAFRSUMAFTPS/Resources/ rped117.pdf (accessed on 15 July 2012).
} 
corruption, ${ }^{95}$ which reduces leakages into private pockets revenues that should accrue to governments. ${ }^{96}$

There are several examples of paperless customs in developing countries resulting in increased government revenue. In Peru, an electronic customs reform program in the 1990s more than doubled the country's revenue collected by Customs (from US\$626 million in 1991 to US\$1.505 billion in 1993) despite a reduction in tariff rates at the same time. ${ }^{97}$ Electronic customs implemented in Angola in 2000 increased revenue receipts by $150 \%$ immediately, while also reducing customs processing and clearance time. ${ }^{98}$ Ghana's electronic customs system introduced in 2001, the GCNet, led to a 30\% increase in revenue collection by customs. ${ }^{99}$

Considering that most African economies rely heavily on revenue from tariffs, the importance of the positive revenue outcomes flowing from electronic customs cannot be underestimated. Higher government revenue means the government can invest in economic development, including trade enhancing, projects.

\subsubsection{Increase in Foreign Direct Investment (FDI)}

As mentioned earlier, FDIs are important for trade expansion in Africa, as they bring in the capital, technology and skills for efficient and competitive production and products. As noted earlier, modern methods of global production require efficient modes of trade logistics, including cheap, swift, transparent and predictable customs services to enable the products to be exported to global markets or other centres in the production chain efficiently. ${ }^{100}$ E-customs in particular, and e-governance systems that reduce corruption and instil efficiencies in general, are of importance to attracting the necessary FDIs for trade expansion.

It has been lamented that many African countries have created reasonably good governments and adopted reasonably sound policies "and yet have failed to attract nonextractive direct investment, or even to promote domestic investment." ${ }^{101}$ In other words the countries have failed to attract investments into their manufacturing

\footnotetext{
95) See The Revised Arusha Declaration: Declaration of the Customs Co-operative Council Concerning Integrity in Customs, Done at Arusha, Tanzania, on the 7th day of July 1993 (81st/82nd Council Sessions) and revised in June 2003 (101st/102nd Council Sessions) clause 4, available http:/www.wcoomd.org/ files/1.\%20Public\%20files/PDFandDocuments/Declarations/Revised_Arusha_Declaration_EN.pdf (accessed on 2 October 2012).

96) See, Wulf and Sokol, supra note 82 , p. 29, stating that " $[\mathrm{t}]$ he losers [from the implementation of Ghana's GCNet] are those CEPS personnel who had previously benefited from substantial facilitation payments that traders had offered to accelerate cargo clearance, to close their eyes when cargo left port premises without a declaration, or to accept declarations that included underinvoicing and erroneous product classifications so as to lower the amount of duties due."

${ }^{97)}$ A. Goorman, 'Peru' in Wulf and Sokol, supra note 82, 65-83, p. 78.

98) E. Moïsé, Trade Facilitation Reforms in the Service of Development: Country Case Studies (OECD, Paris, 22 February 2005) 11-12.

99) L. De Wulf, 'Ghana', in Wulf and Sokol, supra note 82,19-32, pp. 25-30.

100) See Engman, supra note 92, p. 103; Krafft and Page, supra note 87.

101) Noman et al., supra note 13, p.6.
} 
and other non-extractive sectors. ${ }^{102}$ This demonstrates the level of competition for capital in the global market place, and Africa's lack of competitiveness in general. It also demonstrates that the determinants of FDI flows into the manufacturing sectors are complex. The importance of trade logistics, and e-customs for that matter, should be seen in that context.

It is not suggested in this article that e-customs is a panacea. E-customs is not a silver bullet for Africa's international trade under-performance; that alone will not attract FDIs into the desired sectors. However, it is an important and relatively easier and cheaper system to implement that has a high potential for competitiveness enhancement. ${ }^{103}$ It is easier, quicker and cheaper to implement because it can be targeted at just the customs and the port (import/export) community. It may be complemented with export free zones and other carefully studied programs that are attractive to FDIs.

\subsubsection{Implementation Issues}

As the benefits of e-customs seem obvious, and the technology is available, the question may arise as to why many African countries may not have implemented such systems. An oft- cited problem is lack of funds. In other words, countries do not have the requisite e-customs systems because they cannot afford, not because they do not appreciate the benefits of such systems. The counter argument is that the implementation of an e-customs system can be done through private sector funding, with little or no demand on the public purse. It can be a source for private sector investment and technology transfer to the implementing economy. An example can be given of Ghana's GCNet, incorporated in October 2000 under a public private partnership (PPP). ${ }^{104}$ The initial cost of project (US\$5.3 million) was contributed by shareholdings as follows: Ghana Government (represented by Ghana Customs Excise and Preventive Service 20\% (contributed in the form of office space and existing equipment)); SGS (Société Générale de Surveillance S.A) 60\%; Ghana Shippers Council 10\%; Ecobank 5\%; and Ghana Commercial Bank 5\%. ${ }^{105}$ Not only has GCNet led to a drop in corruption within Customs ${ }^{106}$ and substantial increase in government revenue collection at the ports, ${ }^{107}$ it has

\footnotetext{
102) Even the investments in the extractive industries "may simply reflect the fact that those countries [are] willing to give away their resources for a low enough price" such that they will always find some company to take them. See Noman et al., supra note 13, p. 6.

103) E-customs is just one piece in the puzzle of the infrastructural and logistical demands of international trade, but it is easier, quicker and cheaper to implement than the others- the building (or upgrading) of road, rail and port networks - which, though very important, costs far more and take much longer to accomplish.

104) Wulf and Sokol, supra note 82, pp. 19-32.

105) Wulf and Sokol, supra note 82, p. 22.

106) Wulf and Sokol, supra note 82, p. 29.

107) Wulf and Sokol, supra note 82, pp. 28-29; V.A. Azeem, 'Ghana' in D. Zinnbauer, R. Dobson and K. Despota (Eds), Global Corruption Report 2009: Corruption and the Private Sector (Cambridge University Press, Cambridge, 2009) 180-183, p. 183.
} 
also been paying good dividends to all shareholders, both private and government. Other examples are Chile, where two-thirds of the total cost of its customs automation project (US\$ 5 million) was funded by private stakeholders, ${ }^{108}$ and The Philippines, which had private investor participants. ${ }^{109}$ Thus, given the right environment, e-customs projects are amenable to private investment, whether foreign or domestic, making it more affordable for all parties involved.

Further, the United Nations Conference on Trade and Development (UNCTAD) has developed technical assistance expertise for e-customs through its ASYCUDA (Automated System for Customs Data) program. ${ }^{110}$ Some African governments have already accessed the program, though not fully implemented so as to enable accrual of all the potential benefits. It must be conceded that there are identifiable flaws in the ASYCUDA program. A 2008 report by the UN's Office of Internal Oversight Services (OIOS) found several flaws in the implementation and management of projects, including the lack of adequate information, lack of adequate assessment of project impact, inadequate post installation support and lack of transparency in technology provider selection. ${ }^{111}$ In fact, there were obvious conflicts of interests involving officials on the project, which undermined the integrity of the program. Further, the licensing system of underlying technology of the ASYCUDA programs can make it difficult for implementing governments to have control over their own customs system. Some countries have abandoned ASYCUDA after initial trials. Ghana, for instance, implemented the ASYCUDA program in the late 1980s and ended it 1994, ${ }^{112}$ before implementing the GCNet in 2000 through a PPP. ${ }^{113}$

In summary, e-customs is affordable. It can be implemented through private sector funding, with little or no demand on the public purse or through technical assistance. While it is not a panacea for Africa's international trade under-performance, it is an important and relatively easier and cheaper infrastructure to implement, and it has a high potential for enhancing the competitiveness of implementing economies.

\footnotetext{
108) Chilean Permanent Mission to the World Trade Organisation, 'Chile's Experience with the Modernization of Customs Administrations Based on the use of Information Technology' (Paper No G/C/W/239, WTO Council for Trade in Goods, 31 October 2000), available at http://www.wto.org/english/tratop_e/ tradfa_e/tradfa_overview2000_e.htm (accessed 20 March 2012).

109) Moïsé, supra note 98, p. 181.

110) More information on ASYCUDA is available at http://www.asycuda.org/ (accessed on 31 July 2012).

111) OIOS, Audit Report: The Automated System for Customs Data (ASYCUDA) Programme of United Nations Conference for Trade and Development (UNCTAD), (4 December 2008), Assignment No. AE2007/541/1 available at http://usun.state.gov/documents/organization/139328.pdf (accessed on 5 June 2012).

112) ASYCUDA, "ASYCUDA User Countries, Territories and Regions, 'Ghana', at http://www.asycuda .org/dispcountry.asp?name=Ghana (accessed 5 August 2012).

113) See text around footnote 104.
} 


\section{Conclusion}

This article has observed that trade expansion is important to the growth and development of African economies. Unfortunately, Africa's share of world trade has been decreasing rather than increase. The continent is behind other continents in developmental terms, despite its many resource endowments. The seeming paradox of underdevelopment amidst resources is the subject of much study.

This article has argued that governance deficiencies (broadly defined) are a major cause of the inability of African economies to manage their resources for sustained growth and development. On governance deficiencies, the article focused on economic mismanagement - meaning: ineffective, inefficient and inequitable management of resources; and corruption - as critical manifestations. It looked at the particular consequences of these deficiencies on trade expansion.

The article has gone on to suggest that the deployment of ICT, particularly in the form of e-governance, can ameliorate those deficiencies. It focused on the potential positive impact of e-governance in general, and e-customs in particular, on trade expansion. It has demonstrated that e-governance can be used to combat corruption. E-customs has the potential to enhance the international competitiveness of African economies, increase revenues for government, and increase FDI inflows for production and exportation. While e-customs it is not a panacea for Africa's international trade under-performance, it is an important piece of infrastructure that is relatively easier and cheaper to build, but which has a high beneficial impact on trade expansion. It is therefore recommended for implementation by African economies that do not yet have efficient e-customs systems. 